\title{
PKM INDUSTRI RUMAHAN PEMBERDAYAAN EKONOMI PEREMPUAN KOTA BITUNG
}

\author{
Quido Kainde \\ Fakultas Teknik, Universitas Negeri Manado \\ email : quidokainde@unima.ac.id
}

\begin{abstract}
ABSTRAK
Kota Bitung adalah salah satu kota di provinsi Sulawesi Utara. Kota ini memiliki perkembangan yang cepat karena terdapat pelabuhan laut yang mendorong percepatan pembangunan. Kota Bitung terletak di timur laut Tanah Minahasa. Wilayah Kota Bitung terdiri dari wilayah daratan yang berada di kaki gunung Dua Saudara dan sebuah pulau yang bernama Lembeh. Banyak penduduk Kota Bitung yang berasal dari suku Sangir, sehingga kebudayaan yang ada di Bitung tidak terlepas dari kebudayaan yang ada di wilayah Nusa Utara tersebut. Kota Bitung merupakan kota industri, khususnya industri perikanan (Wikipedia). Berdasarkan kesepakatan dengan Mitra yaitu Dinas Pemberdayaan Perempuan dan Perlindungan Anak Kota Bitung, persoalan yang akan coba diselesaikan adalah peningkatan daya ekonomi perempuan / ibu-ibu rumah tangga pelaku industry rumahan, kurangnya pengetahuan teknologi yang bisa dijadikan alat untuk media promosi produk industry rumahan dan kurangnya penerapan media ICT untuk menaikkan income produk industry rumahan. Beberapa solusi yang ditawarkan dalam menyelesaikan permasalahan yang dihadapi oleh mitra antara lain: pemberian pelatihan ICT swakelola industry rumahan bagi perempuan / ibu-ibu rumah tangga pelaku industry rumahan, pemberian buku panduan pelatihan pemanfaatan ICT untuk industry rumahan. Luaran yang akan dihasilkan dari masing-masing solusi atas permasalahan yang dihadapi mitra ada 2 luaran yaitu Jasa dan Produk Buku Panduan. Hasil artikel dari pelaksanaan program PKM ini akan dipublikasikan dalam jurnal nasional / internasional yang terindeks.
\end{abstract}

Kata Kunci: Industri Rumahan, ICT, Pemberdayaan Perempuan 


\section{PENDAHULUAN}

Teknologi Informasi dan Komunikasi (TIK) dewasa ini sudah berkembang begitu pesat, baik dari sisi teknologinya maupun bidang penggunaannya. Alat-alat seperti komputer/tablet/smartphone yang tadinya hanya dipakai dengan keperluan terbatas, sekarang sudah berubah dan dipakai dengan berbagai macam manfaat. Mulai dari pendidikan, perbankan, sampai dengan perdagangan.

Teknologi telekomunikasi khususnya internet dapat digunakan untuk menjembatani informasi dan pengetahuan yang tersebar di dunia maya kepada seluruh masyarakat yang membutuhkan. Salah satu diantaranya adalah pelaku industri rumahan dikalangan perempuan. Akses terhadap komunikasi digital ini dapat membantu meningkatkan akses pelaku industri rumahan untuk meningkatkan peluang perdagangan dan pemasaran, akses informasi untuk pelatihan, mendapatkan jaringan dan peluang peningkatan pendapatan bagi perempuan dan peluang tenaga kerja.

Para perempuan pelaku Industri Rumahan dapat menggunakan TIK menjadi alat yang efektif untuk mengembangkan usahanya. Namun demikian, peran perempuan di dalam perkembangan TIK masih minoritas. Laki-laki masih memegang peranan penting dalam penggunaan TIK. Perempuan mendominasi pada posisi administrasi, memasukkan data, operator komputer, dan sejenisnya, selebihnya dipegang laki-laki. Dengan kata lain, TIK bagi perempuan di negara berkembang merupakan barang mewah yang sulit diakses. Oleh karena itu dalam rangka pengembangan industri rumahan yang umumnya di dominasi oleh kaum perempuan, perlu dilakukan pengembangan dan peningkatan kemampuan dalam hal pengoperasian Teknologi Informasidan Komunikasi (TIK) untuk meningkatkan produktiitas pelaku ekonomi.

Kota Bitung adalah salah satu kota di provinsi Sulawesi Utara. Kota ini memiliki perkembangan yang cepat karena terdapat pelabuhan laut yang mendorong percepatan pembangunan. Kota Bitung terletak di timur laut Tanah Minahasa. Wilayah Kota Bitung terdiri dari wilayah daratan yang berada di kaki gunung Dua Saudara dan sebuah pulau yang bernama Lembeh. Banyak penduduk Kota Bitung yang berasal dari suku Sangir, sehingga kebudayaan yang ada di Bitung tidak terlepas dari kebudayaan yang ada di wilayah Nusa Utara tersebut. Kota Bitung merupakan kota industri, khususnya industri perikanan.(Wikipedia).

Penduduk Kota Bitung berdasarkan proyeksi penduduk tahun 2017 sebanyak 212.409 jiwa yang terdiri atas - jiwa penduduk laki-laki dan - jiwa penduduk perempuan. Dibandingkan dengan proyeksi jumlah penduduk tahun 2010, penduduk Kota Bitung mengalami pertumbuhan sebesar 1,74 persen tiap tahunnya. Sementara itu besarnya angka rasio jenis kelamin tahun 2017 penduduk lakilaki terhadap penduduk perempuan sebesar 104.38. Angka ini menunjukkan bahwa setiap 100 penduduk perempuan terdapat 104/105 penduduk laki-laki di Kota Bitung. Kepadatan penduduk di KotaBitung tahun 2017 mencapai 677 jiwa $/ \mathrm{km} 2$. Kepadatan Penduduk di 8 kecamatan cukup beragam dengan kepadatan penduduk tertinggi terletak di kecamatan Girian dengan kepadatan sebesar 6,044jiwa/km2 dan terendah di Kecamatan Ranowulu, masing-masing sebesar 130 jiwa/Km2. Kecamatan Matuari menjadi kawasan dengan perumahan pemukiman terluas dengan luas sebesar $458.35 \mathrm{Ha}$ diikuti dengan kecamatan Madidir dengan luas 330.74 Ha.

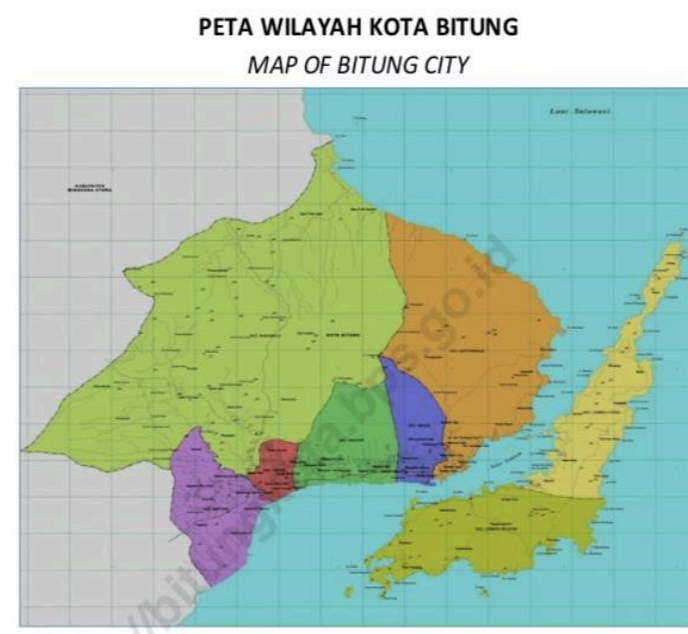

Pelatihan ini diharapakan dapat memberikan kemampuan kepada Ibu-ibu pelaku Industri Rumahan dalam hal mengenal hal-hal umum yang terkait dengan TIK, mampu melakukan pencarian informasi menggunakan internet, mampu menghitung biaya produksi dan harga jual, mampu memasarkan produk menggunakan media sosial, mampu membuat surat menyurat menggunakan komputer dan mampu membuat profil usahanya sendiri untuk pengajuan kebutuhan dana. 
2. SOLUSI PERMASALAHAN Permasalahan

Sebagai tempat pelaksanaan kegiatan kemitraan masyarakat ini adalah Dinas Pemberdayaan Perempuan dan Perlindungan Anak Kota Tomohon. Permasalahan yang teridentifikasi yang menjadi titik tolak kegiatan kemitraan pada masyarakat yang diusulkan terfokus pada beberapa masalah yang dihadapi mitra yakni:

1. Banyak keluarga yang masih digaris kemiskinan

2. Banyak ibu -ibu rumah tangga yang tidak bekerja dan tidak memiliki penghasilan tambahan keluarga.

3. Banyak ibu-ibu pelaku industri rumahan yang kurang pemahaman ICT

4. Banyak ibu-ibu pelaku industri rumahan tidak tahu cara memasarkan produk industri mereka

5. Kurangnya pengetahuan tentang teknologi informasi dalam akses informasi, mencari peluang perdagangan dan peningkatan income bagi keluarga

\section{Solusi}

Berdasarkan permasalahan yang dihadapi mitra, maka solusi dari pelaksanaan program kegiatan PKM ini adalah sebagai berikut:

1. Memberikan pelatihan pemanfaatan ICT untuk ibu-ibu rumah tangga pelaku industry rumahan Kota Bitung

2. Memberikan pemahaman tentang menghitung biaya produksi dan harga jual

3. Memberikan pengetahuan tentang pemanfaaatan media social untuk promosi

4. Memberikan pengetahuan tentang cara berkorespondensi / surat menyurat

5. Memberikan pengetahuan tentang cara membuat profil usaha dan pengujuan kebutuhan dana

\section{METODE PELAKSANAAN \\ Persiapan}

Tahapan ini dilakukan setelah dilaksanakan pemilihan mitra, survey dan analisa situasi terhadap lokasi kegiatan. Kegiatan yang dilakukan pada tahapan ini adalah tim pelaksana berkomunikasi dengan Dinas Pemberdayaan Perempuan dan Perlindungan Anak Kota Bitung yang akan menjadi mitra untuk membicarakan maksud dan tujuan, serta mekanisme pelaksanaan kegiatan ini. Selain itu juga membicarakan hal-hal teknis yang mengenai pelaksanaan kegiatan. Setelah mengkoordinasikan pelaksanaan kegiatan maka tim pelaksana menyusun program pelatihan atau workshop. Selain itu juga pada tahapan ini dilakukan pengumpulan alat dan bahan yang akan digunakan.

a. Materi Pelatihan

Materi yang disampaikan dalam pelatihan ini terdiri dari 6 (enam) kompetensi yang harus dimiliki oleh pelaku industri rumahan, diantaranya adalah:

1. Pengenalan ICT.

2. Mencari Informasi Menggunakan Internet.

3. Menghitung Biaya Usaha.

4. Melakukan Pemasaran melalui Media Sosial dan Pembuatan Brosur Sederhana.

5. Membuat Korespondensi (Surat Menyurat).

6. Profil Usaha dan Proposal Pengajuan Kebutuhan Dana.

b. Peserta Pelatihan

Peserta pelatihan adalah 50 perempuan / ibu-ibu rumah tangga pelaku industry rumahan yang mendapatkan rekomendasi dari Dinas Pemberdayaan Perempuan dan Perlindungan anak.

c. Rencana Jadwal Pelaksanaan

Tabel. Timeline Pelaksanaan

\begin{tabular}{|c|c|c|c|c|}
\hline No & Kegiatan & $\begin{array}{l}\text { Durasi } \\
\text { Waktu } \\
\text { (menit) }\end{array}$ & $\begin{array}{c}\text { Waktu } \\
\text { Pelaksanaan }\end{array}$ & Tempat \\
\hline 1 & $\begin{array}{l}\text { Pembukaan oleh } \\
\text { Dinas KPPA Kota } \\
\text { Bitung }\end{array}$ & 15 & $08.00-08.15$ & mengikuti \\
\hline 2 & Pengenalan ICT & 30 & $08.15-08.45$ & \\
\hline 3 & $\begin{array}{l}\text { Mencari informasi } \\
\text { menggunakan } \\
\text { internet }\end{array}$ & 60 & $08.45-09.45$ & \\
\hline 4 & Rehat 1 & 15 & $09.45-10.00$ & \\
\hline 5 & $\begin{array}{l}\text { Menghitung biaya } \\
\text { usaha }\end{array}$ & 60 & $10.00-11.00$ & \\
\hline 6 & $\begin{array}{l}\text { Melaksanakan } \\
\text { pemasaran melalui } \\
\text { Media Sosial dan } \\
\text { Pembuatan Brosur } \\
\text { sederhana (1) }\end{array}$ & 60 & $11.00-12.00$ & \\
\hline 7 & Ishoma & 60 & $12.00-13.00$ & \\
\hline 8 & $\begin{array}{l}\text { Melaksanakan } \\
\text { pemasaran melalui } \\
\text { Media Sosial dan }\end{array}$ & 45 & $13.00-13.45$ & \\
\hline
\end{tabular}




\begin{tabular}{|l|l|c|c|}
\hline & $\begin{array}{l}\text { Pembuatan Brosur } \\
\text { sederhana (2) }\end{array}$ & & \\
\hline 9 & $\begin{array}{l}\text { Membuat } \\
\text { korespondensi }\end{array}$ & 45 & $13.45-14.30$ \\
\hline 10 & $\begin{array}{l}\text { Profil usaha dan } \\
\text { proposal } \\
\text { pengajuan } \\
\text { kebutuhan dana }\end{array}$ & 45 & $14.30-15.15$ \\
\hline 11 & Rehat 2 & 15 & $15.15-16.00$ \\
\hline 12 & Penutup & 30 & $16.00-16.30$ \\
\hline
\end{tabular}

\section{Pelaksanaan}

Dalam pelaksanaan kegiatan, dilakukan persiapan terlebih dahulu yakni pengecekan kembali seluruh peralatan yang akan digunakan oleh peserta.

\section{Evaluasi dan Refleksi}

Evaluasi adalah rangkaian kegiatan membandingkan realisasi masukan (input), keluaran (output), dan hasil (outcome) terhadap rencana dan standar. Evaluasi merupakan merupakan kegiatan yang menilai hasil yang diperoleh selama kegiatan pemantauan berlangsung. Lebih dari itu, evaluasi juga menilai hasil atau produk yang telah dihasilkan dari suatu rangkaian program sebagai dasar mengambil keputusan tentang tingkat keberhasilan yang telah dicapai dan tindakan selanjutnya yang diperlukan.

Evaluasi pelaksanaan program setelah kegiatan PKM selesai, dilakukan dengan cara:

- Setiap program kegiatan yang telah dilaksanakan diberikan angket untuk diisi oleh seluruh peserta yang mengikuti program kegiatan.

- Setelah pelaksanaan PKM, penanda tanganan Pakta Integritas untuk menjamin semua yang sudah disampaikan/dilatihankan dapat dilakukan secara terus-menerus untuk menjaga penyelenggaraan pemerintahan desa dengan layanan prima.

- Pendampingan terus menerus untuk peserta pelatihan sehingga kegiatan ini berjalan secara terus menerus

\section{HASIL DAN PEMBAHASAN}

\section{Pelaksanaan}

Pelaksanaan PKM bagi para pelaku Industri Rumahan Pemberdayaan Ekonomi Kota Bitung berjalan dengan baik. Jumlah peserta yang menghadiri pelatihan ini sebanyak 40 orang dengan latar pelaku industri rumahan berbeda-beda. Saat kedatangan peserta, mereka langsung registrasi dan mendapatkan fasilitas untuk pelatihan misalnya buku panduan pelatihan. Sebelum pembukaan dimulai, peserta yang sudah datang, masuk ke dalam ruangan diberikan kesempatan untuk menjawab pre-test.

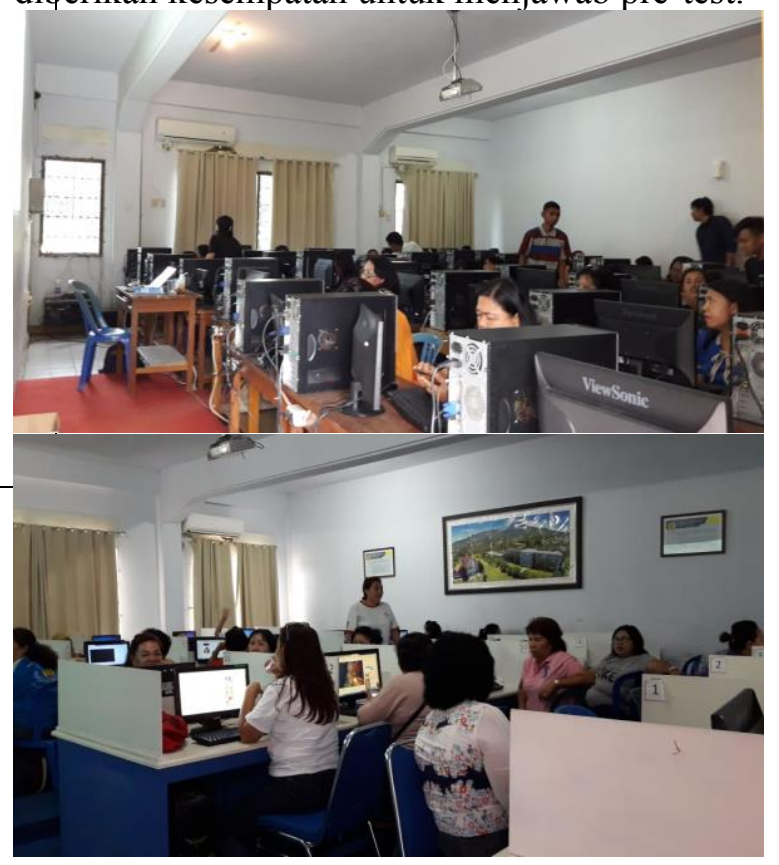

\section{Evaluasi}

Penilaian evaluasi PKM bagi para pelaku Industri Rumahan yang telah diisi oleh 40 peserta pelatihan didapatkan:

a. Pre-Test

- Bagaimana kemampuan anda menggunakan computer (tablet, notebook,pc)?

Umumnya peserta belum mahir dalam menggunakan computer. 18 peserta pelatihan belum pernah menggunakan. 14 peserta sangat kurang dalam menggunakan komputer (tablet, laptop atau pc) dan baik dalam kemampuan mengoperasikannya.

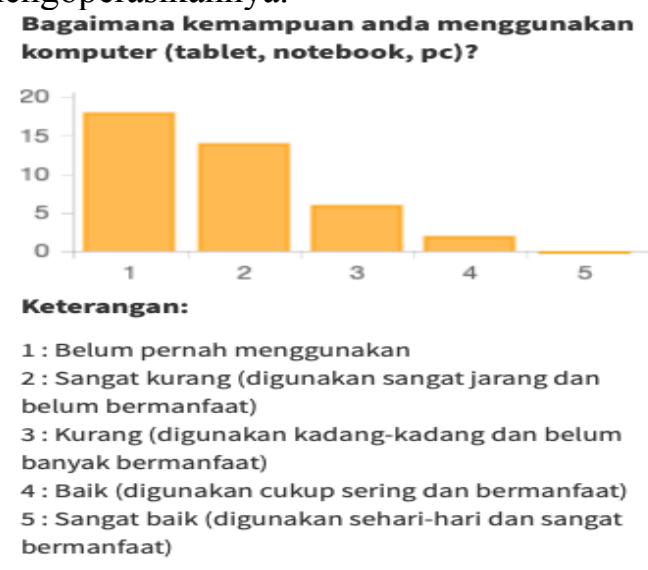

Bagaimana kemampuan anda menggunakan ponsel, smartphone?

23 peserta masih kurang (menggunaan kadang kadang dan belum banyak bermanfaat). 10 orang 
sudah cukup sering dan bermanfaat menggunakan ponsel, smartphone.

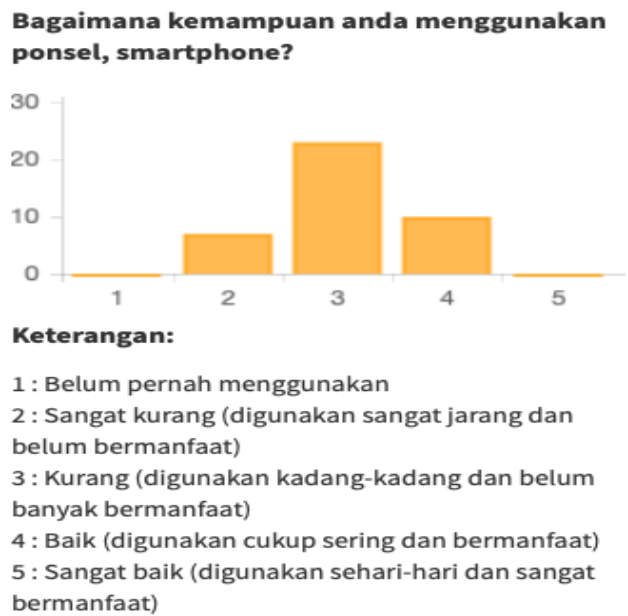

Bagaimana anda memanfaatkan teknologi informasi (termasuk internet) untuk pemasaran / promosi?

Terlihat hampir semua peserta masih kurang dalam penggunaan teknologi informasi.

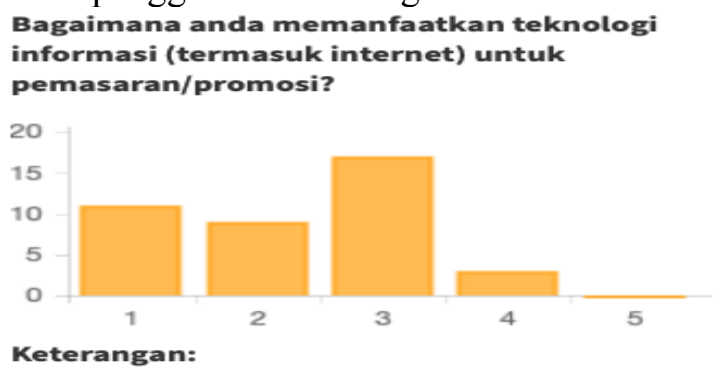

1: Belum pernah menggunakan

2 : Sangat kurang (digunakan sangat jarang dan

belum bermanfaat)

3: Kurang (digunakan kadang-kadang dan belum banyak bermanfaat)

4 : Baik (digunakan cukup sering dan bermanfaat)

5 : Sangat baik (digunakan sehari-hari dan sangat bermanfaat)

- Bagaimana anda memanfaatkan teknologi informasi (termasuk internet) untuk penjualan (pemesanan, pembayaran, informasi lain yang menunjang proses penjualan)?

Dalam pemanfaata teknologi informasi (termasuk internet) untuk penjualan, ibu-ibu peserta IR sebagian besar masih kurang. Bagaimana anda memanfaatkan teknologi informasi (termasuk internet) untuk penjualan (pemesanan, pembayaran, informasi lain yang menunjang proses penjualan)?

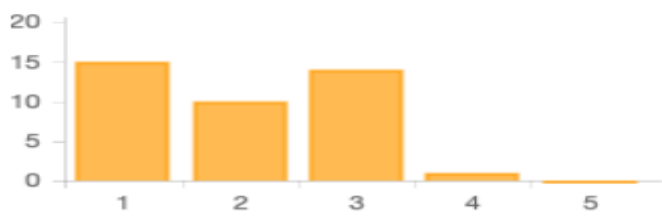

\section{Keterangan:}

1 : Belum pernah menggunakan

2 : Sangat kurang (digunakan sangat jarang dan belum bermanfaat)

3 : Kurang (digunakan kadang-kadang dan belum banyak bermanfaat)

4: Baik (digunakan cukup sering dan bermanfaat)

5 : Sangat baik (digunakan sehari-hari dan sangat bermanfaat)

- Bagaimana minat anda untuk belajar memanfaatkan teknologi informasi?

Sebagian besar peserta menjawab berminat dan siap meluangkan waktu, menyediakan alat dan mencoba memakai ICT.

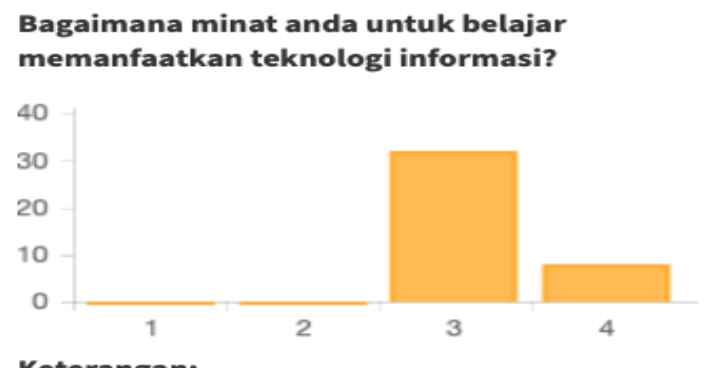

Keterangan:

1: Tidak berminat sama sekali

2: Kurang berminat

3 : Berminat (siap meluangkan waktu,

menyediakan alat, mencoba memakai)

4 : Sangat berminat (siap meluangkan waktu,

menyediakan alat, mencoba memakai secara

maksimal)

b. Post-Test

Dari hasil setelah dilakukan pelatihan IR dengan menggunakan ICT, terlihat bahwa ibu-ibu sudah siap dalam menerapkan ICT secara dan akan mengajarkan apa yang dilatih ke yang lain.

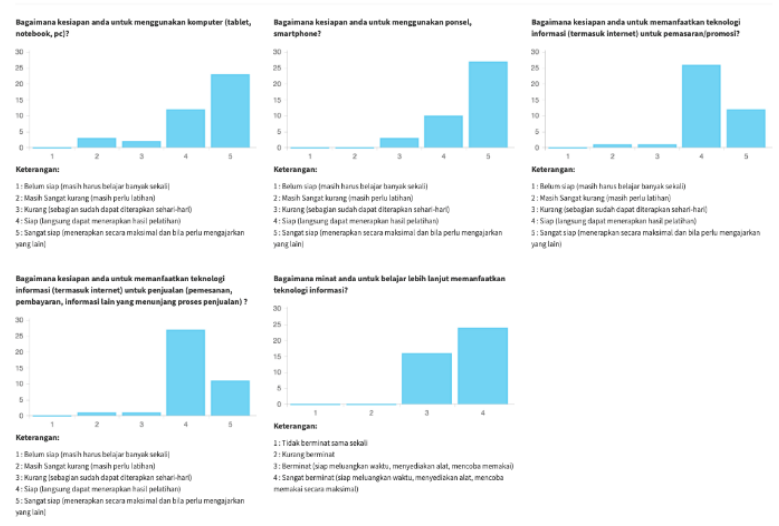




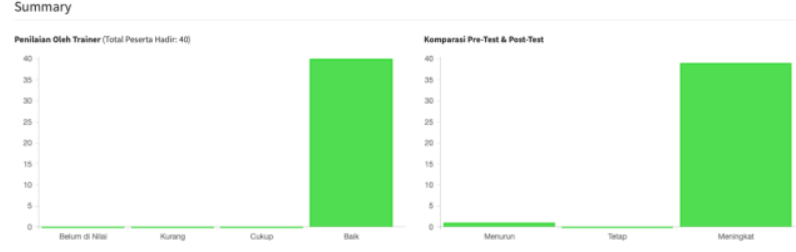

\section{KESIMPULAN}

Berdasarkan hasil pelaksanaan kegiatan yang telah dilakukan, dapat disimpulkan bahwa pelaksanaan PKM pelatihan ICT bagi ibu-ibu pelaku industry rumahan sangatlah baik. Sejumlah ibu-ibu peserta kegiatan sangatlah antusias dan banyak memberikan pertanyaan mengenai persoalan pemasaran yang mereka hadapi di lapangan dan masukkan untuk pelaksanaan kedepannya.

\section{REFERENSI}

1. BPS, 2018. Kota Bitung Dalam Angka. Badan Pusat Statistik Kota Bitung.

2. KPPA. 2017. Buku Panduan Peserta, Pelatihan Pemanfaatan ICT untuk Industri Rumahan. Kementrian Pemberdayaan Perempuan dan Perlindungan Anak RI. 